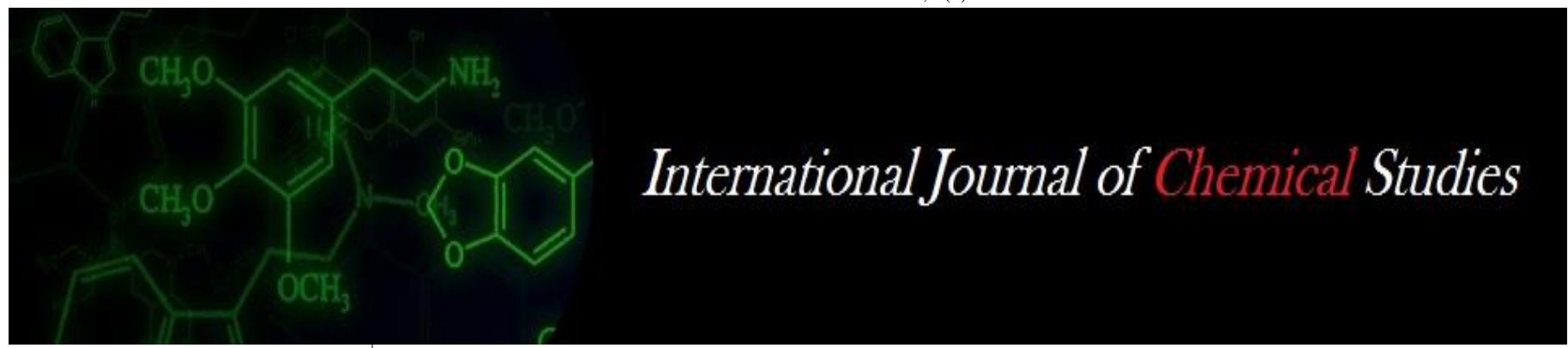

P-ISSN: 2349-8528

E-ISSN: 2321-4902

www.chemijournal.com

IJCS 2021; 9(1): 804-807

(C) 2021 IJCS

Received: 27-11-2020

Accepted: 30-12-2020

Kalyani D Deshmukh

M.Sc. Scholar, Department of

Horticulture, VNMKV,

Parbhani, Maharashtra, India

Vishwanath S Khandare

Research Officer, Department of

Horticulture Research Scheme

Vegetable, VNMKV, Parbhani,

Maharashtra, India

Sonam D Jadhav

M.Sc. Scholar, Department of

Horticulture, VNMKV,

Parbhani, Maharashtra, India
Corresponding Author: Kalyani D Deshmukh M.Sc. Scholar, Department of Horticulture, VNMKV, Parbhani, Maharashtra, India

\section{Detection of presence of non-allelic interaction for yield and yield contributing characters in okra Abelmoschus esculentus L. Moench}

\author{
Kalyani D Deshmukh, Vishwanath S Khandare and Sonam D Jadhav
}

DOI: https://doi.org/10.22271/chemi.2021.v9.i1k.11325

\begin{abstract}
The experimental material comprised of six generations $\left(\mathrm{P}_{1}, \mathrm{P}_{2}, \mathrm{~F}_{1}, \mathrm{~F}_{2}, \mathrm{BC}_{1}\right.$ and $\left.\mathrm{BC}_{2}\right)$ through generation mean analysis of six crosses with different parents. The generations were analysed during kharif 2019 in Randomized Block Design with randomization of generations within each cross in two replications. The traits were studied number of ridges per pod, number of seeds per pod, weight of 10 seeds (g), weight of 100 seeds $(\mathrm{g})$. The scaling test indicated the presence of non-allelic interaction in all the crosses. In all the crosses PBNOK-6 x Pusa Makhmali was observed superior in most of the characters. In the most of the crosses the dominance (h) component was observed to be important in the inheritance of characters like weight of 10 seeds, weight of 100 seeds and additive $x$ dominance (j) interaction was showed importance in number of ridges per pod, number of seeds per pod. Most of the characters showed complementary type of gene action. Complementary type of gene action play role in transfer inheritance characters. Some characters showed duplicate type of epistasis. Its play important role for transgressive selection of the characters.
\end{abstract}

Keywords: Okra, generation mean analysis, yield components, gene effects, epistasis

\section{Introduction}

Okra is one of the important vegetable crop grown during spring summer and rainy season. It has cultivation, export potential and high nutritive value. Okra is highly energetic of variable leading position among vegetables due to its wide adoptability and year round nutrients. It is commonly known as bhindi or lady's finger, belongs to the class dicotyledonae, order Malvales and family Malvaceae. Okra flowers are often cross-pollinated crop with somatic chromosome number $2 n=130$. In India, okra is trading crop grown in the states of Gujrat, Maharashtra, Andhra Pradesh, Tamil Nadu, Karnataka. It is grown all over the tropical and sub-tropical regions as well as in the warmer parts of the temperate regions. The yield potential of okra is low with straight varieties (10.39t/ha) shows that there is a big difference in productivity. It is an introduced vegetable crop in India. It is extensively grown for its tender pods, which are used as a very popular, tasty and gelatinous vegetable, it is a highly energetic of valuable nutrients. It has massive socio-economic potential for enhancing livelihoods in both rural and urban areas.

\section{Materials and Methods}

The experimental material in present consideration comprises six crosses PBNOK $2 x$ Parbhani Bhendi, PBNOK 2 x Parbhani Kranti, PBNOK 2 x Pusa Makhmali, PBNOK 4 x Parbhani Bhendi, PBNOK 6 x Pusa Makhmali, VRO 103 x Hissar Naveen along with their parental lines PBNOK-2, PBNOK-2, PBNOK-2, PBNOK-4, PBNOK-6, VRO-103, Parbhani Bhendi, Parbhani Bhendi, Parbhani Kranti, Pusa Makhmali, Pusa Makhmali, Hissar Naveen. The experiment was conducted at the Experimental Farm, Horticulture Research Scheme (Vegetable), Vasantrao Naik Marathwada Krishi Vidyapeeth, Parbhani. The generations were analysed during kharif 2019 in Randomized Block Design with randomization of generations within each cross in two replications. In each replication observations were recorded on 5 random competitive plant of $\mathrm{P}_{1}, \mathrm{P}_{2}, \mathrm{~F}_{1}, 20$ plants on $\mathrm{F}_{2}$ and $\mathrm{BC}_{1}, \mathrm{BC}_{2}$ on 15 plants. 
The treatments showing significant differences for the traits were subjected to generation mean analysis and determination of gene effects using six parameter models as suggested by Hayman (1958) ${ }^{[5]}$. Chi-square test were calculated as per joint scaling test (Cavalli 1952) ${ }^{[4]}$. Presence of non-allelic gene interactions in all the crosses indicated in scaling test. Duplicate type of interaction and complementary epistasis in six crosses estimated gene effects for different traits.

\section{Result and Discussion}

Scaling test were performed as given by Hayman (1958) ${ }^{[5]}$. Scaling tests viz., A, B, C, D (Table 1), showed presence of appreciable amount of epistasis in different characters. Presence of epistatic gene action for yield and its related traits have been reported earlier by Panda and Singh (2003) ${ }^{[10]}$, Akthar et al. (2010), Mistry (2013) ${ }^{[9]}$ and Soher et al. (2013) [13] which confirmed present results. The chi square $\left(\mathrm{x}^{2}\right)$ values were significant according to joint scaling test for first fruiting node in all six crosses studied. The significant value of chi square for this trait in all the crosses indicated that the three parameter model did not adequately explain the genetic variability for these traits. The inadequacy of the model was also indicated the presence of epistasis (non-allelic gene interaction), which was also inferred from the generation means. As the three parameter model did not satisfactorily explain the genetic variability for this trait, therefore, a six parameter model was applied to accommodate epistatic interactions. The results showed that non-allelic gene interactions of six parameter model of generation mean analysis was presented in Table 2. Estimate of gene effects from the generation mean analysis mean effect (m) was positively significant.

\section{Number of ridges per pod}

In number of ridges per pod, additive (d) component positively significant in four crosses PBNOK-2 x Parbhani Bhendi, PBNOK-2 x Parbhani Kranti, PBNOK-4 x Parbhani Bhendi and VRO-103 x Hissar Naveen. The two crosses viz., PBNOK-2 x Pusa Makhmali and PBNOK-6 x Pusa Makhmali was showed negatively significant. The dominance (h) component and additive $\mathrm{x}$ additive (i) interaction positively significant in five crosses. Additive $\mathrm{x}$ dominance interaction (j) negatively significant in two crosses and three crosses was found positively significant. Dominance $\mathrm{x}$ dominance interaction (1) was showed negatively significant in five crosses. and cross PBNOK-4 x Parbhani Bhendi were found positively significant. Duplicate type of interaction was observed to be presented in five crosses. In the cross PBNOK$2 \times$ Parbhani Bhendi indicating complimentary type of gene effect. The similar results was found by Salameh et al. (2007) [11].

\section{Number of seeds per pod}

The number of seeds per pod, the Additive component (d) interaction which was showed negatively significant in cross PBNOK-2 x Parbhani Bhendi and cross PBNOK-6 x Pusa Makhmali was showed positively significant. The dominance (h) component were showed positively significant in five crosses. The additive $\mathrm{x}$ additive (i) type of interaction was negatively significant in two crosses and four crosses positively significant. The additive $x$ dominance (j) interaction was showed to be negatively significant in the four crosses and cross VRO-103 x Hissar Naveen was showed positively significant. Dominance $\mathrm{x}$ dominance type of interaction (1) effect was positively significant in two crosses and cross PBNOK-6 x Pusa Makhmali negatively significant. Complimentary type of interaction was found to be presented in five crosses. In the cross PBNOK-6 x Pusa Makhmali indicating duplicate type of gene effect. Similar results were found by Soher et al. (2013) ${ }^{[13]}$.

Weight of 10 seeds (g): The estimate of gene effects for weight of 10 seeds, dominance (h) component was found to be positively significant in all crosses. The additive (d) component positively significant in three crosses. Additive $\mathrm{x}$ additive (i) component was positively significant in two crosses. The additive $x$ dominance $(j)$ and dominance $x$ dominance (l) interaction was found positively significant in three crosses and cross PBNOK-2 x Parbhani Bhendi was negatively significant. Duplicate type of interaction was found to be presented in two crosses. The four crosses indicated complimentary type of gene effect. The similar results were found by Abdelmageed (2010) ${ }^{[1]}$.

\section{Weight of 100 seeds (g)}

In the weight of 100 seeds, the Additive component (d) was negatively significant in four crosses and PBNOK-4 $\mathrm{x}$ Parbhani bhendi were showed positively significant. In the four crosses was showed positively significant and two crosses PBNOK-2 x Parbhani Bhendi, VRO-103 x Hissar naveen was showed negatively significant for dominance (h) component. The gene effect of additive $x$ additive (i) interaction was negatively significant in the five crosses and three crosses were showed negatively significant and the cross PBNOK-2 x Parbhani Bhendi was observed positively significant interaction for additive $\mathrm{x}$ dominance $(\mathrm{j})$ component. The dominance $\mathrm{x}$ dominance (l) component was showed positively significant in four crosses. Duplicate type of interaction was found to be presented in two crosses PBNOK-2 x Parbhani Bhendi and VRO-103 x Hissar Naveen and four crosses indicated complimentary type of gene effect. The similar results were observed with previous findings by Soher et al. (2013) ${ }^{[13]}$.

Table 1: Scaling test for 19 characters in 6 crosses of okra

\begin{tabular}{|c|c|c|c|c|}
\hline Character and crosses & $\mathbf{A}$ & B & $\mathbf{C}$ & $\mathbf{D}$ \\
\hline \multicolumn{5}{|c|}{ Number of rigdes per pod } \\
\hline PBNOK 2 X Parbhani Bhendi & $-027 * * \pm 0.00$ & $0.43^{* *} \pm 0.00$ & $-0.10 \pm 0.01$ & $-0.13^{*} \pm 0.00$ \\
\hline PBNOK 2 X Parbhani Kranti & $0.17 \pm 0.01$ & $0.10 \pm 0.00$ & $-0.50 * * \pm 0.01$ & $-0.38 * * \pm 0.00$ \\
\hline PBNOK 2 X Pusa Makhmali & $0.74 * * \pm 0.00$ & $0.44 * * \pm 0.01$ & $0.90 * * \pm 0.01$ & $-0.14 * * \pm 0.00$ \\
\hline PBNOK 4 X Parbhani Bhendi & $0.20 \pm 0.01$ & $-0.50 * * \pm 0.00$ & $-0.20 \pm 0.02$ & $0.05 \pm 0.00$ \\
\hline PBNOK 6 X Pusa Makhmali & $0.30^{*} \pm 0.02$ & $1.47 * * \pm 0.00$ & $1.30 * * \pm 0.02$ & $-0.23^{* *} \pm 0.00$ \\
\hline VRO 103 X Hissar Naveen & $0.23 * * \pm 0.00$ & $-0.10 \pm 0.00$ & $0.00 \pm 0.01$ & $-0.06^{* *} \pm 0.00$ \\
\hline \multicolumn{5}{|c|}{ Number of seeds per pod } \\
\hline PBNOK 2 X Parbhani Bhendi & $-6.37 * * \pm 1.08$ & $-4.43 * * \pm 1.47$ & $-15.70 * * \pm 5.03$ & $-2.45^{* *} \pm 0.89$ \\
\hline PBNOK 2 X Parbhani Kranti & $-4.34 * * \pm 0.24$ & $0.40 \pm 0.98$ & $-7.20 * * \pm 1.18$ & $-1.63 * * \pm 0.07$ \\
\hline PBNOK 2 X Pusa Makhmali & $-4.10 * * \pm 0.99$ & $-0.43 \pm 2.09$ & $-7.80 * * \pm 4.47$ & $-1.63 \pm 0.84$ \\
\hline
\end{tabular}




\begin{tabular}{|c|c|c|c|c|}
\hline PBNOK 4 X Parbhani Bhendi & $1.03 \pm 1.06$ & $4.47^{* *} \pm 0.52$ & $10.60^{* *} \pm 1.70$ & $2.55^{* *} \pm 0.39$ \\
\hline PBNOK 6 X Pusa Makhmali & $-2.80^{* *} \pm 0.03$ & $0.37 \pm 1.00$ & $-8.30^{* *} \pm 1.05$ & $-2.93^{* *} \pm 0.01$ \\
\hline VRO 103 X Hissar Naveen & $3.10^{* *} \pm 0.23$ & $-2.33^{* *} \pm 0.20$ & $5.50^{* *} \pm 0.10$ & $2.36^{* *} \pm 0.09$ \\
\hline \multicolumn{7}{|c|}{ Weight of 10 seeds } \\
\hline PBNOK 2 X Parbhani Bhendi & $-0.01 \pm 0.00$ & $-0.02 \pm 0.00$ & $-0.31^{* *} \pm 0.00$ & $-0.14^{* *} \pm 0.00$ \\
\hline PBNOK 2 X Parbhani Kranti & $-0.00 \pm 0.00$ & $-0.27^{* *} \pm 0.00$ & $-0.28^{*} \pm 0.01$ & $0.00 \pm 0.00$ \\
\hline PBNOK 2 X Pusa Makhmali & $-0.00 \pm 0.00$ & $-0.26^{* *} \pm 0.00$ & $-0.27^{*} \pm 0.01$ & $0.00 \pm 0.00$ \\
\hline PBNOK 4 X Parbhani Bhendi & $-0.10^{* *} \pm 0.00$ & $-0.28^{* *} \pm 0.00$ & $-0.26^{* *} \pm 0.00$ & $0.06^{*} \pm 0.00$ \\
\hline PBNOK 6 X Pusa Makhmali & $-0.05 \pm 0.00$ & $-0.10 \pm 0.00$ & $-0.09 \pm 0.01$ & $0.03^{*} \pm 0.00$ \\
\hline VRO 103 X Hissar Naveen & $-0.14^{* *} \pm 0.00$ & $-0.04 \pm 0.00$ & $-0.41^{* *} \pm 0.00$ & $-0.11^{* *} \pm 0.0$ \\
\hline Weight of 100 seeds & $-0.44 \pm 0.29$ & $0.67 \pm 0.15$ & $0.40 \pm 0.67$ & $0.08^{* *} \pm 0.00$ \\
\hline PBNOK 2 X Parbhani Bhendi & $-1.06^{* *} \pm 0.01$ & $-1.28^{* *} \pm 0.00$ & $-1.22^{* *} \pm 0.05$ & $0.56^{* *} \pm 0.00$ \\
\hline PBNOK 2 X Parbhani Kranti & $-1.31^{* *} \pm 0.02$ & $-0.34 \pm 0.03$ & $-1.22^{* *} \pm 0.03$ & $0.21^{* *} \pm 0.03$ \\
\hline PBNOK 2 X Pusa Makhmali & $-1.31^{* *} \pm 0.00$ & $-0.33 \pm 0.03$ & $-1.21^{* *} \pm 0.04$ & $0.21^{* *} \pm 0.00$ \\
\hline PBNOK 4 X Parbhani Bhendi & $-0.11 \pm 0.05$ & $-0.85^{* *} \pm 0.06$ & $-1.35^{* *} \pm 0.21$ & $-0.19 \pm 0.01$ \\
\hline PBNOK 6 X Pusa Makhmali & $-0.83^{* *} \pm 0.03$ & $-0.59^{* *} \pm 0.00$ & $-0.67^{* *} \pm 0.02$ & $0.37^{* *} \pm 0.00$ \\
\hline VRO 103 X Hissar Naveen & $-0.57^{*} \pm 0.07$ & $1.05^{* *} \pm 0.12$ & $2.16^{* *} \pm 0.28$ & $0.84^{* * \pm 0} \pm 0.08$ \\
\hline
\end{tabular}

Table 2: Estimation of gene effects of 6 crosses for 19 characters in okra

\begin{tabular}{|c|c|c|c|c|c|c|c|c|}
\hline Character and crosses & M & d & $\mathbf{h}$ & i & $\mathbf{j}$ & $\mathbf{L}$ & $\begin{array}{c}\text { Type of } \\
\text { epistasis }\end{array}$ & $\begin{array}{c}\mathrm{X} 2 \\
\text { values }\end{array}$ \\
\hline \multicolumn{9}{|c|}{ Number of ridges per pod } \\
\hline $\begin{array}{c}\text { PBNOK } 2 \text { X Parbhani } \\
\text { Bhendi }\end{array}$ & $5.35 * * \pm 0.02$ & $0.10 * * \pm 0.02$ & $-0.09 \pm 0.11$ & $0.26^{* *} \pm 0.10$ & $.35^{* *} \pm 0.03$ & $-0.42 * * \pm 0.14$ & Complementary & $\mathrm{S}$ \\
\hline $\begin{array}{c}\text { PBNOK } 2 \text { X Parbhani } \\
\text { Kranti }\end{array}$ & $5.27 * * \pm 0.01$ & $0.13 * * \pm 0.04$ & $0.97 * * \pm 0.12$ & $0.77 * * \pm 0.11$ & $0.03 \pm 0.06$ & $-10.4 * * \pm 0.23$ & Duplicate & $\mathrm{S}$ \\
\hline PBNOK 2 X Pusa Makhmali & $5.35 * * \pm 0.00$ & $.10 * * \pm 0.04$ & $0.03 \pm 0.10$ & $0.28 * * \pm 0.08$ & $.15 * \pm 0.06$ & $1.46 * * \pm 0.19$ & Duplicate & $\mathrm{S}$ \\
\hline $\begin{array}{c}\text { PBNOK } 4 \text { X Parbhani } \\
\text { Bhendi }\end{array}$ & $5.37 * * \pm 0.01$ & $0.10 * * \pm 0.03$ & $-0.15 \pm 0.10$ & $-0.10 \pm 0.07$ & $0.35^{* *} \pm 0.04$ & $0.40^{*} \pm$ & Duplicate & $\mathrm{S}$ \\
\hline PBNOK 6 X Pusa Makhmali & $5.50 * * \pm 0.00$ & $.43^{* *} \pm 0.01$ & $0.32 * * \pm 0.08$ & $0.47 * * \pm 0.02$ & $.58^{* *} \pm 0.07$ & $-2.24 * * \pm 0.16$ & Duplicate & $\mathrm{S}$ \\
\hline VRO $103 \times \mathrm{X} \mathrm{H}$ & 5.4 & 00 & $0.33^{*}$ & $0.13 * *$ & 04 & & & $\mathrm{~S}$ \\
\hline \multicolumn{9}{|c|}{ Number of seeds per pod } \\
\hline $\begin{array}{c}\text { PBNOK } 2 \text { X Parbhani } \\
\text { Bhendi }\end{array}$ & $41.87 * * \pm 0.42$ & $-0.87 * \pm 0.39$ & $9.50 * * \pm 2.02$ & $4.90 * * \pm 1.89$ & $-0.97 \pm 0.77$ & $5.90 * \pm 2.75$ & Complementary & $\mathrm{S}$ \\
\hline $\begin{array}{c}\text { PBNOK } 2 \text { X Parbhani } \\
\text { Kranti } \\
\end{array}$ & $41.95 * * \pm 0.07$ & $0.13 \pm 0.24$ & $10.36^{* *} \pm 0.77$ & $3.26^{* *} \pm 0.56$ & $-2.37^{* *} \pm 0.52$ & $0.68 \pm 1.45$ & Complementary & $\mathrm{S}$ \\
\hline PBNOK 2 X Pusa Makhmali & $43.80 * * \pm 0.38$ & $36 \pm 0.50$ & $6.77 * * \pm 1.98$ & $3.27 * \pm 1.84$ & $.83^{*} \pm 0.87$ & $1.26 \pm 2.93$ & Con & $\mathrm{S}$ \\
\hline $\begin{array}{c}\text { PBNOK } 4 \text { X Parbhani } \\
\text { Bhendi }\end{array}$ & $45.82 * * \pm 0.21$ & $-0.37 \pm 0.46$ & $-1.25 \pm 1.35$ & $-5.10 * * \pm 1.26$ & $-1.72 * * \pm 0.57$ & $-0.40 \pm 2.27$ & Complementary & $\mathrm{S}$ \\
\hline PBNOK 6 X Pl & \pm 0.04 & 0.07 & 0.56 & 0.24 & 0.50 & $-3.44 * * \pm 1.06$ & te & $\mathrm{S}$ \\
\hline VRO & \pm 0.03 & 0 & $1.92 * *$ & $-4.73 * *$ & & \pm 1.24 & ary & $\mathrm{S}$ \\
\hline \multicolumn{9}{|c|}{ Weight of 10 seeds } \\
\hline $\begin{array}{c}\text { PBNOK } 2 \text { X Parbhani } \\
\text { Bhendi }\end{array}$ & $0.52 * * \pm 0.00$ & $0.01 \pm 0.00$ & $0.63 * * \pm 0.02$ & $0.28 * * \pm 0.01$ & $0.00 \pm 0.01$ & $-0.24 * * \pm 0.05$ & Duplicate & $\mathrm{S}$ \\
\hline $\begin{array}{c}\text { PBNOK } 2 \text { X Parbhani } \\
\text { Kranti }\end{array}$ & $0.53 * * \pm 0.00$ & $0.04 * * \pm 0.00$ & $0.18 * * \pm 0.06$ & $0.00 \pm 0.02$ & $0.13 * * \pm 0.02$ & $0.28 * \pm 0.11$ & Complementary & $\mathrm{S}$ \\
\hline PBNOK 2 X Pusa Makhmali & $* * \pm 0.01$ & 03 & $8 * * \pm 0.05$ & 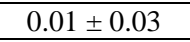 & 01 & 12 & entary & $\mathrm{S}$ \\
\hline $\begin{array}{c}\text { PBNOK } 4 \text { X Parbhani } \\
\text { Bhendi }\end{array}$ & $0.60 * * \pm 0.01$ & $0.03 * * \pm 0.01$ & $0.26 * *$ & $-0.13 * \pm 0.06$ & $0.09 * * \pm 0.02$ & $0.52 * * \pm 0.08$ & Complementary & $\mathrm{S}$ \\
\hline PBNOK 6 X Pusa Makhmali & $0 * * \pm 0.00$ & $0 \pm 0.00$ & $* * \pm 0.06$ & $6 * \pm 0.02$ & $* \pm 0.01$ & 0.13 & entary & $\mathrm{S}$ \\
\hline VRO 103 X Hissar Naveen & $0.49 * * \pm 0.00$ & $-0.03 \pm 0.02$ & $0.33 * * \pm 0.05$ & $0.23 * * \pm 0.05$ & $-0.05 * \pm$ & & & $\mathrm{S}$ \\
\hline \multicolumn{9}{|c|}{ Weight of 100 seeds } \\
\hline $\begin{array}{c}\text { PBNOK } 2 \text { X Parbhani } \\
\text { Bhendi }\end{array}$ & $* * \pm 0.03$ & $-0.11 * *$ & 0.18 & 0.15 & .06 & $=0.25$ & Duplicate & $\mathrm{S}$ \\
\hline $\begin{array}{c}\text { PBNOK } 2 \text { X Parbhani } \\
\text { Kranti } \\
\end{array}$ & $4.75 * * \pm 0.02$ & $-0.61 * * \pm 0.02$ & $0.95 * * \pm 0.14$ & $-0.43 * * \pm 0.11$ & $-0.48 * * \pm 0.09$ & $2.07 * *$ & Complementary & $\mathrm{S}$ \\
\hline PBNOK 2 X Pusa Makhmali & $4.75^{* *} \pm 0.00$ & $-0.62 * * \pm 0.02$ & $0.95 * * \pm 0.13$ & $-0.42 * * \pm 0.12$ & $-0.49 * * \pm 0.09$ & $2.07 * * \pm 0.23$ & Complementary & $\mathrm{S}$ \\
\hline $\begin{array}{c}\text { PBNOK } 4 \text { X Parbhani } \\
\text { Bhendi }\end{array}$ & $* * \pm($ & 0. & $0.85 * * \pm$ & \pm 0.23 & $0.37 \pm$ & 0.5 & Complementary & $\mathrm{S}$ \\
\hline PBNOK 6 X Pusa Makhmali & $4.53 * * \pm 0.02$ & $-0.11 \pm 0.08$ & $0.76 * * \pm 0.19$ & $-0.75 * * \pm 0.18$ & $-0.12 \pm 0.09$ & $2.17 * * \pm 0.35$ & Complementary & $\mathrm{S}$ \\
\hline VRO 103 X Hissar Naveen & $5.05 * * \pm 0.11$ & $-0.66^{* *} \pm 0.18$ & $-1.55^{* *} \pm 0.60$ & $-1.69^{* *} \pm 0.59$ & $-0.81 * * \pm 0.22$ & $1.21 \pm 0.90$ & Duplicate & $\mathrm{S}$ \\
\hline
\end{tabular}

\section{References}

1. Abdelmageed AHA. Inheritance studies of some economic characters in okra [Abelmoschus esculentus (L.) Moench]. Tropical and Subtropical Agroecosystems 2010;12:619-627.

2. Allolli S, Jagtap VS, Ahamed Z. Generation mean analysis with respect of yield and percent incidence of fruit borer and yellow vain mosaic virus (YVMV) in okra [Abelmoschus esculentus (L.) Moench]. Journal of
Pharmacognosy and Phytochemistry 2020;9(1):23052308.

3. Arora D, Jindal SK, Ghai TR. Generation mean analysis for earliness related traits in okra [Abelmoschus esculentus (L.) Moench]. Electronic Journal of Plant Breeding 2010;1(6):1434-1442.

4. Cavalli LL. An analysis of Linkage in quantitative inheritance, "Quantitative inheritance" H. M. Stationary Office. London 1952, P135-144. 
5. Hayman BI. The separation of epistatic from additive and dominance variation in generation means. Heredity 1958;12:371-390.

6. Jinks JI, Jones RM. The analysis of diallel crosses. Maize genetics co-operative News Letter 1958;27:48-54.

7. Mather K, Jinks JL. Introduction to biometrical genetics. Chapman and Hall, London 1977, P237.

8. Mahajan RC, Sonawane DJ, Yamgar SV. Estimation of generation mean analysis and scaling test for fruit yield and its attributing traits in okra [Abelmoschus esculentus (L.) Moench]. Journal of Pharmacognosy and Phytochemistry 2017;6(6):2128-2135.

9. Mistry PM. Generation mean analysis in okra. [Abelmoschus esculentus (L.) Moench] Agricultural Science Digest 2013;33(1):21-26.

10. Panda PK, Singh KP. Generation mean analysis for yield and yield traits in okra. [Abelmoschus esculentus (L.) Moench]. Vegetable Science 2003;30(1):25-28.

11. Salameh MN, Kasrawi AM. Inheritance of fruit length, diameter and number of ridges per pod [Abelmoschus esculentus (L.) Moench]. Jordan Journal of Agricultural Sciences 2007;3(4):439-452.

12. Sindhumole P, Manju P. Genetic architecture to yellow vein mosaic and leaf spot diseases in okra [Abelmoschus esculentus (L.) Moench]. Electronic journal of plant breeding 2015;6(1):157-160.

13. Soher EA, EI-Gendy, Abd EI-Aziz MH. Generation mean analysis of economic traits in okra [Abelmoschus esculentus (L.) Moench]. Journal of Applied Sciences 2013;13(6):810-818.

14. Verma A, Sood S. Gene action studies on yield and quality traits in okra [Abelmoschus esculentus (L.) Moench]. African Journal of agricultural research 2015;10(43):4006-4009.

15. Wakode MM, Bhave SG, Navhale VC, Dalvi VV, Mahadik SG. Genetic analysis of yield and yield contributing traits in okra. Electronic Journal of Plant Breeding 2015;6(4):956-961. 